\title{
Impact of Spring Freshet Flooding and Summer Rainfall Flooding on the Water Quality of an Alpine Barrier Lake
}

Chun-hua LI

Chinese Research Academy of Environmental Sciences

Chun Ye ( $\nabla$ yechun@craes.org.cn )

Chinese Research Academy of Environmental Sciences https://orcid.org/0000-0001-5926-2708

Ji-xuan LI

Shanghai Wuchuan Environment company

Wei-wei WEI

Chinese research academy of environmental research

Ye ZHENG

Chinese research academy of environmental sciences

Ming KONG

Nanjing Institute of Environmental Science, MEE

Hao WANG

Chinese research academy of environmental sciences

\section{Research}

Keywords: barrier lake, spring freshet flooding, summer rainfall flooding, water quality, Lake Jingpo, flooding effect, model simulation

Posted Date: February 26th, 2020

DOI: https://doi.org/10.21203/rs.2.18667/v2

License: (1) (i) This work is licensed under a Creative Commons Attribution 4.0 International License. Read Full License

Version of Record: A version of this preprint was published at Environmental Sciences Europe on April 7th, 2020. See the published version at https://doi.org/10.1186/s12302-020-00319-4. 


\section{Abstract}

Background: Barrier lakes, formed by river interception, are particularly influenced by the upstream river. As such, spring freshet flooding and summer rainfall flooding due to wet precipitation (e.g. snow and rainfall) may sharply increase the concentrations of nitrogen, phosphorous and carbon compounds in barrier lakes. Too much nutrients will lead to lake eutrophication. In this study, we used Lake Jingpo, the world's second largest alpine barrier lake, to examine the impact of spring freshet flooding and summer rainfall flooding on its water quality by building a hydrodynamic water-quality model with MIKE 21 .

Results:The MIKE $21 \mathrm{HD}$ hydrodynamic model and MIKE 21 AD convection and diffusion module were calibrated using meteorological data, hydrological data, and water quality data collected in 2018. All errors were in the acceptable range. According to model simulation results, the flow velocity in Lake Jingpo is generally weak (mostly lower than $0.015 \mathrm{~m} / \mathrm{s}$ ), but it increases to $0.045 \mathrm{~m} / \mathrm{s}$ and above during spring freshet flooding (April-May) and summer rainfall flooding (August-September), which is much higher than in other months. The flow volume of its largest inflowing river reaches $4.81 \times 108 \mathrm{m3}$, $29.77 \times 108 \mathrm{~m} 3$, and $58.4 \times 108 \mathrm{~m} 3$ during spring freshet flooding, summer rainfall flooding, and 30-year frequency rainfall flooding period, respectively. The longest diffusion distances from the lake mouth to the downstream way are $16.3 \mathrm{~km}, 33.1 \mathrm{~km}$, and $43.6 \mathrm{~km}$ during the spring freshet flooding, summer rainfall flooding, and 30-year frequency rainfall flooding period, respectively. A larger amount of precipitation leads to longer diffusion distances and increased concentrations of total nitrogen (TN), total phosphorous (TP), chemical oxygen demand (CODMn), and ammonia-nitrogen ( $\mathrm{NH} 4-\mathrm{N})$ in the lake.

Conclusions: The sudden increase in water volume during spring flooding and summer rainfall flooding led to the rapid spread of nutrients and pollutants carried by the water into the barrier lake, resulting in a deterioration of lake water quality. In addition to pollution source control measures, ecological restoration and the construction of a buffer system in the catchment are very important measures to effectively improve the buffer capacity of barrier lakes in light of spring freshet flooding and summer rainfall flooding.

\section{Background}

Barrier lakes attract special attention due to their unique formation process. They are formed by river interception which results from events such as volcanic lava flows, earthquake-induced landslides, glaciotectonic disturbance, or anthropogenically activities (Xu et al., 2009; Liu et al., 2010). River interception events may obstruct water flow and collect water in valleys or riverbeds. Some barrier lakes have been anthropogenically created on large rivers to generate hydroelectric power. An example is the Kananaskis barrier lake in Alberta, Canada (Bunt et al., 1999). Based on topography and/or the formation process, barrier lakes can be further divided into alpine barrier, lava barrier, and moraine barrier lakes.

Upstream rivers and wet precipitation are the two important natural water supply sources for lakes. Usually, barrier lakes and the original rivers have close relationships, and they are more affected by the 
upstream rivers than other types of lake. Wet precipitation, including snow and rainfall, has the chance to form spring flooding and summer rainfall flooding which flows into the barrier lake via upstream river(s). According to previous research, both the frequency and intensity of summer rainfall flooding are increasing in many places (Groisman et al., 2005; Walsh et al., 2014; Cooney et al., 2019) because mean global land precipitation has increased due to global warming (Kundzewicz, 2005). In this context, spring freshet and summer rainfall flooding both increase barrier lake instability while also impacting water quality. Spring freshet flooding comes from late spring melts, while summer rainfall flooding often occurs in the summer and autumn (Smith et al., 2011). Owing to their special structures, barrier lakes continually interact with their original bodies of water, which are usually large rivers. Alpine barrier lakes are surrounded by mountains. As such, snowmelt or rainfall runoff that move through inflowing rivers and mountains play important roles in the natural processes associated with barrier lakes (Chao and Seo, 2007; Dorum et al., 2010).

However, it is difficult to use real-time monitoring data to explain the impacts of spring freshet and summer rainfall flooding on lake water quality, because of insufficient manual monitoring times and the impact of flood disturbance on automatic monitoring systems. Thus, model simulation techniques are now being increasingly applied to simulate the impacts of these events on both water quantity and quality in many lakes (Moore, 2007; Chen et al., 2015; Zhang et al., 2017). Among these simulation tools is the commonly used MIKE 21 software. MIKE 21 is a comprehensive modelling system used to simulate hydraulics and hydraulic-related phenomena in different bodies of water. The system contains a wide range of engineering and environmental applications that can be used to examine coastal hydraulics, oceanography, wave dynamics, harbours, rivers, environmental hydraulics, and sediment processes (Warren and Bach, 1992; Chubarenko and Tchepikova, 2001; Soltani et al., 2017). After more than 25 years of continuous development and improvement, MIKE 21 now combines the experiences of thousands of worldwide users. It also includes many different modules. For example, it includes the Advection Dispersion Module (AD), which can simulate the transport process of dissolved matter in water due to convection and diffusion, and the Hydrodynamics (HD) module, which can simulate changes in water level and flow caused by various forces. MIKE 21 contains an extensive range of hydraulic phenomena and can be used to simulate any two-dimensional free-surface flow that ignores stratification. An increasing number of engineers and scientists around the world now rely on MIKE 21 as a key simulation tool (Williams et al., 2014; Winterbourn et al., 2016; Kuang et al., 2017).

It is hypothesized that spring freshet flooding and summer rainfall flooding will affect the water quantity and quality of the barrier lakes to a certain extent. However, the relative contributions of spring freshet and summer rainfall flooding to water quality deterioration in barrier lakes, and how long the longest diffusion distances of spring and summer flooding in barrier lakes, are still unknown.

In this study, we used Lake Jingpo, the world's second largest alpine barrier lake (Yang et al., 2010), as a case study to explore the impact of spring freshet and summer rainfall flooding on water quality by building a hydrodynamic water-quality model using MIKE 21. Here, spring freshet flooding refers to the flooding which originates from the melting of ice in April and May. Summer rainfall flooding is the 
flooding which results from the rainfall season during July-September. Additionally, in order to study the impact of high-intensity summer rainfall flooding, we used 30-year frequency rainfall flooding as an extreme example. The probability of 30-year frequency rainfall flooding occurring in any one year is $0.33 \%$. The study of Lake Jingpo will aid the understanding of the law of hydrodynamic force and water quality change in barrier lakes and other similar lakes which connect with a large river.

The aims of this study are: (1) to simulate the annual variations in the flow field of a typical alpine barrier lake using the MIKE $21 \mathrm{HD}$ hydrodynamic model, (2) to simulate the impacts of spring freshet flooding, summer rainfall flooding, and 30-year frequency rainfall flooding on water quality (by measuring the concentrations of total nitrogen (TN), total phosphorous (TP), chemical oxygen demand $\left(\mathrm{COD}_{\mathrm{Mn}}\right)$, and ammonia-nitrogen $\triangle \mathrm{NH}_{4}-\mathrm{N} \mathbb{}$ ) of the lake in order to determine the scope and duration of impact of the three flooding periods using the MIKE 21 AD convection and diffusion module, and (3) to provide scientific support for the subsequent control of lake pollution.

$\mathrm{TN}, \mathrm{TP}, \mathrm{COD}_{\mathrm{Mn}}$ and $\mathrm{NH}_{4}-\mathrm{N}$ concentrations were selected to reflect lake water quality because TN, TP and $\mathrm{COD}_{\mathrm{Mn}}$ concentrations have close relationship with lake eutrophication, while high $\mathrm{NH}_{4}-\mathrm{N}$ concentration has a negative influence on aquatic plants and animals (Bachmann, 1997).

\section{Methods}

\section{Study area}

Lake Jingpo, a typical alpine lava barrier lake, is located in northeast China ( $43^{\circ} 46^{\prime}-44^{\circ} 18^{\prime}$, E 128 ${ }^{\circ} 30^{\prime}-129^{\circ} 30^{\prime}$ ). It was formed by several volcanic eruptions that intercepted the Mudanjiang River, which is both the outflowing and largest inflowing river of Lake Jingpo catchment. It has a water area of $91.5 \mathrm{~km}^{2}$ and a water storage capacity of $11.8 \times 10^{8} \mathrm{~m}^{3}$. The total area of the Lake Jingpo catchment measures $11,664.67 \mathrm{~km}^{2}$, of which $79.8 \%$ is in Jilin Province, while the remaining $20.2 \%$ is in Heilongjiang Province (Fig. 1). The dominate land uses in the catchment are forestlands, which account for $70.7 \%$ and arable lands which account for $23 \%$.

Annual average precipitation of Lake Jingpo catchment measures $549 \mathrm{~mm}$. Summer precipitation (JuneAugust) accounts for approximately $61 \%$ of the annual total. The snowfall period lasts from October to March; the average snowfall period is 172 days. It usually begins to freeze during mid-to-late October and gradually begins to melt in March of the following year. The annual average temperature of lake catchment is as low as $3.5^{\circ} \mathrm{C}$.

The water exchange period totals 116.7 days ( 3.13 times per year). The annual variation characteristics of Lake Jingpo's water level are as follows: The highest water level mainly occurs during the main rainfall period (from August to September), while the lowest water level mainly occurs from March to April, the annual average water level is $347.95 \mathrm{~m}$, the highest water level is $354.43 \mathrm{~m}$, and the lowest water level is $339.17 \mathrm{~m}$. A total of 11 main inflowing rivers enter Lake Jingpo (Fig. 1). The upper reaches of the 
Mudanjiang River are its main source of water inflow. The surface of the river measures approximately 50-150 $\mathrm{m}$ in width, while its normal water depth is $1.0-2.0 \mathrm{~m}$, and the maximum and minimum velocities have been rated at $2.75 \mathrm{~m} / \mathrm{s}$ and $0.09 \mathrm{~m} / \mathrm{s}$, respectively. Lake water is mainly recharged by surface runoff; the Mudanjiang River inflows an average of 2.53 billion $\mathrm{m}^{3} /$ year. Indeed, it accounts for $68.6 \%$ of the total river inflow into the lake, which is 2.18 times the total inflow of all other rivers. The outflowing water from Lake Jingpo is mainly used to generate hydraulic power. After discharging from the power plant, water enters the outflowing Mudanjiang River through an underground passage. Further, part of the water body flows into the Mudanjiang River through the Diaojiaolou Fall at the northern end of the lake.

\section{Data collection}

Meteorological data from Dashazuizi Station, a local hydrological monitoring station located at the Mudanjiang River estuary, were derived from China surface climate readings (http://www.cma.gov.cn/taken by the China Meteorological Science Data Sharing Service Network. A map of the underwater elevation of the lake (using Yellow Sea Height data) is shown in Fig. 2. We collected all the hydrological data and water quality data used in this study. Because most flooding volume will enter barrier lake via inflowing rivers, the inflowing rivers' flow data and water quality data are important inputting parameters used in model simulation.

For the largest river (Mudanjiang River) flowing into Lake Jingpo, we collected its flow volume and water quality parameters at Dashanzuizi Station. For the other small inflowing or outflowing rivers, both river flow volume and water quality samples were collected by our research group (using an Acoustic Doppler Velocimeter; Link Quest ADCP, Flow Quest 2000-AFA-BC, USA). These small rivers sampling sites are indicated by black dots in Fig. 2. These data were collected for one whole year of 2018, they can be found in the Supplementary Material, named as 'River flow' and 'River water quality'. Fig. $\mathrm{S} 1$ in Support Information shows the daily average flow volume $\left(\mathrm{m}^{3} / \mathrm{s}\right)$ at Dashanzuizi Station in 2018.

The daily flow volume of Hydraulic Power Plant of year 2018 were collected for MIKE 21 HD model calibration (see Supplementary Material, 'Hydraulic Power Plant').

When calibrating the water quality model, we used the water quality at 20 sites of Lake Jingpo (Fig. 2, \#1-\#20). The sampling time is September, 2018. TN, TP, $\mathrm{COD}_{\mathrm{Mn}}$ and $\mathrm{NH}_{4}-\mathrm{N}$ concentrations were analysed following the practical manual of environmental monitoring method standards of China (Environmental Monitoring of China, 2013). Table 1 shows the concentrations of $\mathrm{TN}, \mathrm{TP}, \mathrm{COD}_{\mathrm{Mn}}$, and $\mathrm{NH}_{4}-\mathrm{N}$ at the 20 water quality sampling sites used in this study. 
Table 1 Lake water quality in September, 2018

\begin{tabular}{c|cccc}
\hline \multirow{2}{*}{ Sampling site no. } & \multicolumn{4}{|c}{ Lake water quality measure $(\mathrm{mg} / \mathrm{L})$} \\
\cline { 2 - 5 } & $\mathrm{TN}$ & $\mathrm{TP}$ & $\mathrm{COD}_{\mathrm{Mn}}$ & $\mathrm{NH}_{4} \mathrm{-N}$ \\
\hline $1 \#$ & 1.70 & 0.14 & 5.32 & 0.56 \\
\hline $2 \#$ & 1.81 & 0.13 & 5.16 & 0.50 \\
\hline $3 \#$ & 1.83 & 0.12 & 5.03 & 0.50 \\
\hline $4 \#$ & 1.79 & 0.12 & 5.46 & 0.67 \\
\hline $5 \#$ & 1.80 & 0.13 & 5.64 & 0.77 \\
\hline $6 \#$ & 1.61 & 0.13 & 5.44 & 0.79 \\
\hline $7 \#$ & 1.68 & 0.12 & 6.08 & 0.43 \\
\hline $8 \#$ & 1.42 & 0.12 & 5.76 & 0.38 \\
\hline $9 \#$ & 1.51 & 0.12 & 5.60 & 0.51 \\
\hline $10 \#$ & 1.49 & 0.12 & 5.34 & 0.49 \\
\hline $11 \#$ & 1.52 & 0.13 & 5.41 & 0.48 \\
\hline $12 \#$ & 1.52 & 0.11 & 5.49 & 0.40 \\
\hline $13 \#$ & 1.19 & 0.10 & 5.57 & 0.47 \\
\hline $14 \#$ & 1.63 & 0.12 & 5.28 & 0.46 \\
\hline $15 \#$ & 1.44 & 0.14 & 5.44 & 0.50 \\
\hline $16 \#$ & 1.53 & 0.12 & 4.70 & 0.61 \\
\hline $17 \#$ & 1.48 & 0.15 & 4.64 & 0.55 \\
\hline $18 \#$ & 1.47 & 0.14 & 5.17 & 0.44 \\
\hline $19 \#$ & 1.45 & 0.12 & 5.44 & 0.66 \\
\hline $20 \#$ & 1.48 & 0.14 & 6.19 & 0.53 \\
\hline & & & &
\end{tabular}

\section{Establishing and calibrating the flow model}

The MIKE 21 HD model was used to build the water flow model. This was done to analyse water balance, study water-level characteristics, and determine velocity variation in the lake area while gathering necessary hydrodynamic field elements for subsequent nutrients or pollutants calculations. As such, a total of 13,500 grid cells were established across the lake's surface area; the model's mesh size was $250 \mathrm{~m}$, while the time step was 60 s. The eddy viscosity coefficient was calculated using the Smagorinsky subgrid scale formula (Smagorinsky coefficient of 0.5 ) and manning roughness factor of $32 \mathrm{~m}^{1 / 3} / \mathrm{s}(\mathrm{Wu}$, 2016).

The MIKE 21 HD model was calibrated using the monitoring data at Hydraulic Power Plant of year 2018. Its water level data (2018/01/01-2018/12/31) can be found in the Support Information (Hydraulic Power Plant). As we know that lake flow current and water level are two basic components for lake hydrodynamic modelling (Wu, 2016). 
However, Lake Jingpo's average current speed is very weak. For example, in-site

measurements showed only $0.038 \mathrm{~m} / \mathrm{s}$ during the period without flooding in 2018 . The weak current speed can therefore be ignored for model calibration and validation and lake water level was selected as the main hydrodynamic characteristic.

Lake flow current and water level are two basic components for lake hydrodynamic (Wu, 2016). However, Lake Jingpo's average current is very weak in light of its not large lake area and narrow shape. For example, in-site measurement showed only $0.038 \mathrm{~m} / \mathrm{s}$ during the period without flooding in 2018. Such weak current speed can be ignored for model calibration and validation. Therefore, lake water level is selected as the main concerned hydrodynamic characteristic.

\section{Establishing and calibrating the water quality model}

We constructed a water quality model using the MIKE 21 AD convection and diffusion module. This model was used to simulate the concentration distributions of $\mathrm{COD}_{\mathrm{Mn}}, \mathrm{NH}_{4}{ }^{-}$ $\mathrm{N}, \mathrm{TN}$, and TP in the lake area during the year 2018.

Model calibration was realized by adjusting the decay coefficient, diffusion coefficient, and non-point source load into the lake.

According to the MIKE 21 user manual (DHI, 2019), the following parameters can be used to construct a water quality model for a barrier lake such as Lake Jingpo:

- Chemical oxygen demand (COD)

- Biochemical oxygen demand (BOD)

- Dissolved oxygen (DO)

- Ammonia/ammonium-N $\left(\mathrm{NH}_{4}-\mathrm{N}\right)$

- Nitrate-N $\left(\mathrm{NO}_{3}-\mathrm{N}\right)$

- TP (the sum of particulate phosphorus [PP] and dissolved phosphorus [DP]). 
A number of transformation processes and interactive relationships are taken into account, for instance the degradation of organic matter, photosynthetic oxygen production, respiration of animals and plants, exchange of oxygen with the atmosphere, oxygen demand from the riverbed, and nitrification and denitrification processes. The processes and concentrations of the parameters are influenced by external factors, such as upstream inflow and near lake discharge.

The required model constants to be derived from experience or by model calibration include:

- Degradation constants

- Temperature coefficients

- Sedimentation rates

- Resuspension rates

- Oxygen production rates

- Respiration rates

- Oxygen consumption rates e.g. during nitrification

- Yield and uptake rates for ammonia/ammonium-N and phosphorus

- Reaction orders and rate constants for nitrification and denitrification

- Adsorption/desorption of phosphorus on suspended solids.

COD is modelled as an advection-dispersion parameter considering a first order decay and exchange of matter with the riverbed (sedimentation/resuspension). In this study, additional outputs used include TN (the sum of $\mathrm{NH}_{4}-\mathrm{N}$ and $\mathrm{NO}_{3}-\mathrm{N}$ ) and TP (the sum of DP and $\mathrm{PP})$.

Fig. 3 shows the Nitrogen compounds and processes included in MIKE 21.

The equations describing the ammonium/ammonia and $\mathrm{NO}_{3}$ mass balance are as follows: 
[Please see the supplementary files section to access the equations.]

Taking into account the uptake of orthophosphate in the production of algae the equation governing the orthophosphate concentration reads:

[See supplementary files.]

We also analysed phytoplankton during 2018-2019. Phytoplankton density is lower in Lake Jingpo than the lakes in warmer areas, because Lake Jingpo is located in a cold area of China. The average phytoplankton density and chlorophyll-a concentration in the summer season are $33 \times 10^{4}$ ind. / L and $5.79 \mu \mathrm{g} / \mathrm{L}$, respectively. Based on these phytoplankton analyses results, we adjusted the phytoplankton growth rate factor, and ran the module until we achieved a satisfactory result.

\section{Model verification}

Water quality measurement data was collected at Dianshita Station (Fig. 2, red dot), which is $15 \mathrm{~km}$ upstream of the outlet of the lake. The data was collected from May 2016 to May 2017, covering four seasons. Data was not collected in November-December 2016 or March-April 2017 because Lake Jingpo is covered with ice during these months, making the collection of samples during this time highly dangerous. The model was run for two years in order to get a reasonable initial concentration distribution. The final 12 months were selected as the verification period.

\section{Scenarios Simulation}

Three scenarios were simulated by the calibrated model. They are spring freshet flooding, summer rainfall flooding and 30-year frequency summer rainfall flooding. Spring freshet flooding typically occurs in April and May for the Lake Jingpo catchment area. This is when the temperature rises above $5{ }^{\circ} \mathrm{C}$ and there is sufficient sunshine to melt the surrounding snow and ice. Along with water, these events carry pollution into the lake. Summer rainfall flooding often hits the Lake Jingpo catchment area in July-September each 
year. 30-year frequency rainfall flooding as an extreme example. The probability of 30-year frequency rainfall flooding occurring in any one year is $0.33 \%$.

TN, TP, COD $\mathrm{Mn}_{\text {and }} \mathrm{NH}_{4}-\mathrm{N}$ concentrations in wet precipitation for 2017-2018 at the Lake Jingpo catchment were provided by the Heilongjiang Academy of Environment Sciences. Their concentrations were as follows: A TN concentration of $3.89 \mathrm{mg} / \mathrm{L}$, TP concentration of $0.015 \mathrm{mg} / \mathrm{L}, \mathrm{NH}_{4}-\mathrm{N}$ concentration of $1.52 \mathrm{mg} / \mathrm{L}$, and $\mathrm{COD}_{\mathrm{Mn}}$ of $11.67 \mathrm{mg} / \mathrm{L}$.

\section{Results}

\section{Model calibration and verification}

The flow model calibration results are shown in Fig. 4. Lake Jingpo's actual measured water level was nearly unchanged from January to February, but trended downward from February to March. The spring freshet season then caused an increase and subsequent decrease from April to June, followed by higher water levels from July to September due to summer rainfall (the highest level was reached at the end of August). The water level gradually decreased from October to December. The simulated mean water level is 350.02 $\mathrm{m}$, while the measured water level is $350.06 \mathrm{~m}$. Compared with the measured water level, the maximum error of the simulated water level is $0.88 \mathrm{~m}$, the minimum error is $0 \mathrm{~m}$, the mean error is $0.26 \mathrm{~m}$, and the Root Mean Square Error (RMSE) is $0.34 \mathrm{~m}$. As such, the twodimensional hydrodynamic model used in this study accurately reflects the hydrodynamic characteristics of Lake Jingpo and is suitable for research.

Water quality model calibration results are shown in Fig. 5, which include the measured water-quality values and those simulated by the model. Here, the model's predictions were

generally very similar to the actual measured values. While there were some differences, all errors were in the acceptable range. The measured and simulated concentration values were similar for $\mathrm{TN}$ in the range of $0-25 \mathrm{~km}$; the variation trend differed only slightly in the rest range, but the concentration difference was only about $0.2 \mathrm{mg} / \mathrm{L}$. The measured and simulated concentration values for TP were very close. While the concentration change 
trends differed in the range of 15-20 km, the difference between concentration values was small. Further, the concentration value changes were $0.10-0.14 \mathrm{mg} / \mathrm{L}$ in the range of $20-40$ $\mathrm{km}$ and the trends were essentially the same between the two group values. There were some differences between the simulated and measured $\mathrm{COD}_{\mathrm{Mn}}$ concentration values.

However, the concentration difference was very small. The two curves showed very similar trends and maximum concentrations were also in similar positions. The concentration differences for $\mathrm{NH}_{4}-\mathrm{N}$ were large in the range of 0-20 km when compared with the simulated concentration curve. However, the variation trends were similar in the range of 20-40 km; the variation ranges and trends for $\mathrm{NH}_{4}-\mathrm{N}$ were also very similar. Table 2 shows the various errors of water quality model calibration. From it, we can see the calibration is satisfactory.

Table 2 Various errors list of water quality model calibration

\begin{tabular}{lcccc}
\hline & $\mathrm{TN}$ & $\mathrm{TP}$ & $\mathrm{COD}_{\mathrm{Mn}}$ & $\mathrm{NH}_{4} \mathrm{-N}$ \\
Mean Simulated & 1.65 & 0.12 & 5.74 & 0.49 \\
Mean Measured & 1.57 & 0.13 & 5.41 & 0.54 \\
RMSE & 0.18 & 0.01 & 0.81 & 0.13 \\
Max.Error & 0.46 & 0.03 & 1.94 & 0.28 \\
Min.Error & 0.01 & 0.00 & 0.00 & 0.00 \\
Mean.Error & 0.13 & 0.01 & 0.55 & 0.10 \\
Relative Error (Max) & $31.53 \% 23.89 \% 37.57 \%$ & $37.66 \%$ \\
Relative Error (Min) & $0.31 \%$ & $0.66 \%$ & $0.07 \%$ & $0.35 \%$ \\
Relative Error (Mean) & $9.05 \%$ & $9.09 \%$ & $10.35 \%$ & $17.18 \%$ \\
\hline
\end{tabular}

Model verification results are shown in Fig. 6. We can see that the simulated data fits the measurement data very well. In addition, statistical data, such as the RMSE, Max.Error, Min.Error, and relative errors are presented in Table 3. The RMSE for $\mathrm{COD}_{\mathrm{Mn}} \mathrm{TN}$, and TP is $0.47 \mathrm{mg} / \mathrm{L}, 0.11 \mathrm{mg} / \mathrm{L}$, and $0.007 \mathrm{mg} / \mathrm{L}$, respectively. 


\begin{tabular}{lcccc}
\hline & $\mathrm{TN}$ & $\mathrm{TP}$ & $\mathrm{COD}_{\mathrm{Mn}} \mathrm{NH}_{4}-\mathrm{N}$ \\
Mean Simulated & 0.88 & 0.34 & 5.4 & 0.27 \\
Mean Measured & 0.8 & 0.32 & 5.3 & 0.28 \\
RMSE & 0.11 & 0.007 & 0.47 & 0.04 \\
Max.Error & 0.24 & 0.013 & 0.75 & 0.07 \\
Min.Error & 0.017 & 0.001 & 0.21 & 0.01 \\
Mean.Error & 0.1 & 0.006 & 0.43 & 0.04 \\
Relative Error (Max) & $30.0 \%$ & $4.1 \%$ & $14.2 \%$ & $25.0 \%$ \\
Relative Error (Min) & $2.1 \%$ & $0.3 \%$ & $4.0 \%$ & $3.6 \%$ \\
Relative Error (Mean) & $12.5 \%$ & $1.9 \%$ & $8.1 \%$ & $14.3 \%$ \\
\hline
\end{tabular}

\section{Annual variations in the flow field of Lake Jingpo}

The icebound season at Lake Jingpo lasts from October to February of the following year. As such, we were only able to analyse changes in the flow field from March to September 2018 (Fig. 7). Results indicate that the lake-area flow field was generally weak (mostly lower than $0.015 \mathrm{~m} / \mathrm{s}$ ). However, flow velocity significantly increased during the spring freshet season (April-May) and summer rainfall flooding period (July-September). The most significant changes were seen in August, when flow velocities were measured at $0.045 \mathrm{~m} / \mathrm{s}$ and above. This was much higher than in other months, thus indicating that spring freshet flooding and summer rainfall flooding have important effects on the flow velocity of Lake Jingpo.

\section{Impact of the spring freshet season on the water quality of Lake Jingpo}

Fig. 8 shows the transportation and diffusion process of the four water parameters (TN, TP, $\mathrm{COD}_{\mathrm{Mn}}$, and $\mathrm{NH}_{4}-\mathrm{N}$ ) over the 24 days of the spring freshet period. The concentrations of $\mathrm{TN}, \mathrm{TP}, \mathrm{COD}_{\mathrm{Mn}}$, and $\mathrm{NH}_{4}-\mathrm{N}$ diffuse with very similar trends; on the first day that spring freshet flooding enters the lake, concentrations in the mouth area rise rapidly (four to ten times the initial value). According to the simulation result, the spring freshet flooding takes 9 days to diffuse to approximately $25 \%$ of the lake area, and takes about 24 days to cover nearly $50 \%$ of the total lake area.

TN concentrations in Lake Jingpo range from $0.7 \mathrm{mg} / \mathrm{L}$ to $1.2 \mathrm{mg} / \mathrm{L}$ before spring freshet flooding enter. When this occurs, TN concentrations at the entrance exceed 1.7 
$\mathrm{mg} / \mathrm{L}$. Nutrients or pollutants gradually diffuse downstream in the direction of flow as more spring freshet flooding enters the lake. As such, TN concentrations in the affected area increase to more than $1.7 \mathrm{mg} / \mathrm{L}$. However, TN concentrations do not significantly increase in the northern lake area due to the limited reach of the spring freshet flooding (as of day 24).

TP concentrations range from $0.08 \mathrm{mg} / \mathrm{L}$ to $0.12 \mathrm{mg} / \mathrm{L}$ before spring freshet flooding enters Lake Jingpo. After this occurs, TP concentrations exceed $0.28 \mathrm{mg} / \mathrm{L}$. The affected area is limited during the early stages. At this time, the downstream lake remains almost totally unaffected. Concentrations will gradually increase in the downstream area with the further diffusion of spring freshet flooding. They will ultimately exceed $0.28 \mathrm{mg} / \mathrm{L} \mathrm{in}$ approximately half the lake area by the end of the impact period.

$\mathrm{COD}_{\mathrm{Mn}}$ concentrations are about $4.2 \mathrm{mg} / \mathrm{L}$ before spring freshet flooding enters the lake area. Concentrations at the lake mouth will rise to $8.4 \mathrm{mg} / \mathrm{L}$ when this first occurs. The continuous transportation of these waters increases $\mathrm{COD}_{\mathrm{Mn}}$ concentrations to $8.4 \mathrm{mg} / \mathrm{L}$ and above in the upstream area, but the downstream area remains virtually unchanged.

$\mathrm{NH}_{4}-\mathrm{N}$ concentrations in Lake Jingpo are about $0.12 \mathrm{mg} / \mathrm{L}$ before spring freshet flooding enters. However, they exceed $0.84 \mathrm{mg} / \mathrm{L}$ when this does occur. The downstream lake area is nearly unaffected during the early influx stage. The continuous diffusion of spring freshet flooding will eventually raise $\mathrm{NH}_{4}-\mathrm{N}$ concentrations to $0.72 \mathrm{mg} / \mathrm{L}$ and above in the upstream area, but the downstream area will remain unaffected.

\section{Impact of summer rainfall flooding on the water quality of Lake Jingpo}

A simulation of the flooding transportation process is shown in Fig. 9. As seen, it generally only takes eight days of summer rainfall flooding to diffuse to around $25 \%$ of the total lake area, and takes approximately 16 days to diffuse to the hydraulic powerplant. Compared to the spring freshet period, this is a faster transfer with a larger impact range. A large amount of precipitation washes the ground and brings in many nutrients and 
pollutants during those times. This sharply increases lake nutrients and other composition loads for a short time and thus impacts water quality.

TN concentrations in most of the lake are $0.2-0.8 \mathrm{mg} / \mathrm{L}$ before the summer rainfall flooding period. However, concentrations at the lake mouth increase to $2.8 \mathrm{mg} / \mathrm{L}$ when this occurs (approximately 14 times higher than before flooding). The entire lake is affected by day 16 , when TN concentrations increase to varying degrees throughout.

TP concentrations are below $0.2 \mathrm{mg} / \mathrm{L}$ before summer rainfall flooding. However, they subsequently increase sharply. By day 16 , TP concentrations exceed $0.42 \mathrm{mg} / \mathrm{L}$ in most of the lake area from Dashanzuizi to the powerplant.

$\mathrm{COD}_{\mathrm{Mn}}$ concentrations are lower than $4.5 \mathrm{mg} / \mathrm{L}$ before the flooding. However, these subsequently increase to more than $11.2 \mathrm{mg} / \mathrm{L}$. The continuous influx of floodwaters enable surface scouring that far exceeds that of the spring freshet period, thereby causing $\mathrm{COD}_{\mathrm{Mn}}$ concentrations in most of the lake to exceed $11.2 \mathrm{mg} / \mathrm{L}$.

$\mathrm{NH}_{4}-\mathrm{N}$ concentrations are approximately $0.2 \mathrm{mg} / \mathrm{L}$ before the flooding enters the lake area. However, those at the lake mouth increase to $1.5 \mathrm{mg} / \mathrm{L}$ when this begins. Continuous rainfall flooding thereafter raises $\mathrm{NH}_{4}-\mathrm{N}$ concentrations to exceed $1.5 \mathrm{mg} / \mathrm{L}$ throughout most of the lake. The maximum $\mathrm{NH}_{4}-\mathrm{N}$ concentrations during these times are around double those of the spring freshet flooding period. Moreover, the polluted lake area is much larger than during the spring freshet flooding period.

\section{Impact of 30-year frequency flooding on the water quality of Lake Jingpo}

We examined the impact of summer rainfall flooding on water quality at Lake Jingpo by simulating 30-year frequency rainfall. Fig. 10 shows the transportation and diffusion processes of TN, TP, $\mathrm{COD}_{\mathrm{Mn}}$, and $\mathrm{NH}_{4}-\mathrm{N}$. The diffusion trends of the concentrations of these four parameters are very similar throughout Lake Jingpo. Their concentrations raise rapidly even on the first day when the flooding entrancing into Lake Jingpo. The flooding affects nearly $50 \%$ of the lake area after only 11 days. Their concentrations peaked on the 
$21^{\text {st }}$ day, after which they begin to decrease gradually. For example, the concentrations of TN and TP increased from about $0.2 \mathrm{mg} / \mathrm{L}$ and $0.06 \mathrm{mg} / \mathrm{L}$ to more than $3 \mathrm{mg} / \mathrm{L}$ and 0.42 $\mathrm{mg} / \mathrm{L}$, respectively, in 11 days. The concentrations of $\mathrm{NH}_{4}-\mathrm{N}$ also increase rapidly, from 0.6 $\mathrm{mg} / \mathrm{L}$ to more than $1.5 \mathrm{mg} / \mathrm{L}$ in 11 days.

\section{Discussion}

\section{Effects of precipitation on water quality at Lake Jingpo}

Lake Jingpo literally translates as "lake as clear as a mirror." This reflects that its water quality was once very good. Lake Jingpo is still a tourist attraction and a shining pearl in northeast China. As recently as 2012, it was designated as a "good water quality lake" by the Ministry of Ecology and Environment, China (Chinese Research Academy of Environmental Sciences, 2019). However, the recent expansion of local farmlands, development of settlements or industry in the upstream area, and vigorous development of tourism have caused nutrient concentrations in the lake to rise (Wang et al., 2015). This is especially evident during the summer rainfall flooding period, when the concentrations of both TN and TP can exceed $2 \mathrm{mg} / \mathrm{L}$ and $0.2 \mathrm{mg} / \mathrm{L}$, respectively. The deteriorating water quality of Lake Jingpo has caused concern among various environmental protection departments. As such, significant efforts should be made to protect Lake Jingpo over the next few years.

The present research reveals that the larger the volume of precipitation, the longer the diffusion distances, and the greater the increase in concentration of $\mathrm{TN}, \mathrm{TP}, \mathrm{COD}_{\mathrm{Mn}}$, and $\mathrm{NH}_{4}-\mathrm{N}$ (Table 4). Mudanjiang is the largest river that enters Lake Jingpo. Its flow reaches $4.81 \times 10^{8} \mathrm{~m}^{3}, 29.77 \times 10^{8} \mathrm{~m}^{3}$, and $58.4 \times 10^{8} \mathrm{~m}^{3}$ during the spring freshet, summer rainfall, and 30-year frequency rainfall flooding periods, respectively. The longest diffusion distances from the lake mouth to the downstream way were $16.3 \mathrm{~km}, 33.1 \mathrm{~km}$, and $43.6 \mathrm{~km}$ during the spring freshet flooding, summer rainfall flooding, and 30-year frequency rainfall flooding period, respectively. Increased concentrations refer to the maximum concentration differences before and after rainfall floodwaters entered the lake and are a measure of 
water quality. A Spearman rank correlation analysis showed that the longest detected diffusion distances and the increased concentration values of all four water quality parameters were significantly positively correlated with water flow from the Mudanjiang River, with $\mathrm{P}<0.01$. That is, our study showed a positive relationship between the Mudanjiang River and overall precipitation, which is similar to the previous study by Zheng et al (2006). Therefore, precipitation plays an important role in the seasonal water quality of Lake Jingpo. Water from the Mudanjiang River flows with tremendous velocity in the upper reaches causing soil wastage that greatly damages standing crops, plantations, settlements, and roads in the catchment area (Liu, 2013).

Table 4. Comparison of water quality at Lake Jingpo for different rainfall periods

\begin{tabular}{|l|c|c|c|c|c|c|}
\hline & \multirow{2}{*}{$\begin{array}{c}\text { Inflow from } \\
\text { Mudanjiang to lake } \\
\left(\mathrm{m}^{3}\right)\end{array}$} & \multicolumn{2}{|c|}{$\begin{array}{c}\text { Longest } \\
\text { diffusion } \\
\text { distance }\end{array}$} & \multicolumn{3}{|c|}{$\begin{array}{c}\text { The increase in concentration } \\
\text { of four parameters }(\mathrm{mg} / \mathrm{L})\end{array}$} \\
\cline { 5 - 7 } & & $\mathrm{TN}$ & $\mathrm{TP}$ & $\mathrm{COD}_{\mathrm{Mn}}$ & $\mathrm{NH}_{4}-\mathrm{N}$ \\
\hline Spring freshet & $4.81 \times 10^{8}$ & 16.3 & 1.00 & 0.16 & 2.4 & 0.64 \\
\hline Rainfall flood & $29.77 \times 10^{8}$ & 33.1 & 2.6 & 0.36 & 4.2 & 1.1 \\
\hline $\begin{array}{l}30 \text {-year } \\
\text { frequency } \\
\text { rainfall flood }\end{array}$ & $58.4 \times 10^{8}$ & 43.6 & 2.8 & 0.39 & 5.6 & 1.2 \\
\hline
\end{tabular}

Similar findings were reported by Hill (1978) in southern Ontario, where the lowest total dissolved solid content was found in February (due to lower runoff), while the highest was found in May (due to much larger runoff from watersheds). Many previous studies have revealed that major pollutant compositions in surface waters can be controlled by the interactions between precipitation and both surface-geological and biological materials (Correll et al., 1999; Garg et al., 2006; Salim et al., 2015). The temporal concentrations of $\mathrm{TN}, \mathrm{TP}, \mathrm{COD}_{\mathrm{Mn}}$, and $\mathrm{NH}_{4}-\mathrm{N}$ in streams and lakes are primarily governed by discharge; these increase with flow (Lesack, 1993). This study investigated the upper reaches of the Jingpo Lake Basin pass, which is a densely populated and industrialized area (Dunhua city). Some parts of the lake are surrounded by arable lands. Rainstorm floodwaters will thus 
carry many contaminants into the lake, thereby causing a rapid increase in nutrient or pollutant concentrations.

\section{Uncertainties in the modelling approach}

Model uncertainties are often associated with model structure, parameters, and inputs (Renard et al., 2010). MIKE 21 does not account for the stratification of the lake. This stratification affects current velocity to some extent. However, the main purpose of the study was to simulate the impact of spring freshet flooding and summer rainfall flooding on lake water quality. Compared with flooding, the influence of stratification is almost negligible. Therefore, we believe that the model uncertainties do not affect the robustness of the main findings of our study.

Another aspect of uncertainty comes from the ecological processes of lakes, such as phytoplankton dynamics. However, this has little influence on the final simulation results because Lake Jingpo is located in a cold area where the annual average temperature is as low as $3.5^{\circ} \mathrm{C}$, and its phytoplankton density is very low as previously described. From the flow simulation result, we can see that flooding diffusion is very fast and mainly occurs within 10-20 days. Under this condition, the impact of phytoplankton growth can be ignored.

Water quality calibration also has some uncertainty because of the insufficient data. The daily data on inflowing and outflowing rivers were available, but not for the whole lake water. Thus, the model predictions for the intra-annual dynamics of water quality remain uncertain. Nonetheless, we used automatic hydrologic station data to verify this mode and we validated our model. The results indicate good model performance.

In conclusion, our approach is based on a number of modelling approaches that are well-evaluated. Our own evaluation of model performance builds trust in the ability of our modelling approach to quantify the simulation of spring freshet flooding and summer rainfall flooding.

\section{Alpine barrier lakes require stricter environmental protection measures}


Barrier lakes are formed when large rivers (usually the main sources of flow) are blocked. As such, both the water quality and quantity of these rivers greatly influence these elements in barrier lakes. With spring freshets and summer rainfall flooding periods, confluent rainwater runoff from lake catchment areas will soon enter the lake along the main river course, thus causing a rapid decline in water quality over a short period of time (e.g., between two weeks and one month). On the other hand, alpine barrier lakes are characterized by high altitudes and cold winters. As such, there is usually an ice-sealing period. Because organic matters do not degrade well in icebound lakes, concentrations in water columns under icebound areas are usually higher (Jin, 1995). The icebound season at Lake Jingpo lasts approximately 18 weeks, while there are four weeks of spring freshets, and 16 weeks of summer rainfall flooding. As such, there are only 10 weeks of good seasonal conditions without inclement climate impacts.

The above analysis indicates that alpine barrier lake environments are more vulnerable to attack by spring freshet flooding and summer rainfall flooding. Therefore, these areas need increased levels of care. In addition to strengthening the control of pollution sources, measures to improve the water quality of the barrier lake should pay due attention to the ecological restoration of the whole basin and the construction of a basin buffer system, so as to effectively improve the buffer capacity of the lake against spring freshet and summer rainfall flooding.

\section{Conclusions}

For the first time, a process-based dynamic model of flow and water quality has been applied to Lake Jingpo, the world's second largest alpine barrier lake. The model projections provide valuable insights into how alpine lake water quality and flow volume can change during spring freshet flooding, summer rainfall flooding, and 30-year frequency summer rainfall flooding. Spring freshet and summer rainfall flooding carry the nutrients and pollutants of the whole basin into the inflowing rivers of the barrier lake, and the rivers then carry them into the barrier lake. The sudden increase in water volume and the acceleration of flow velocity during these flooding periods causes the nutrients and pollutants carried into the lake to spread rapidly, resulting in the decline in barrier lake water quality.

The results will be invaluable for planners and local stakeholders to assess the impacts of environmental change in Lake Jingpo and can be used to support planning and strategic decision making for other similar barrier lakes. For alpine barrier lakes, in addition to strengthening the control of pollution sources, 
ecological restoration of the whole basin and the construction of a lake buffer system are needed to effectively improve the buffer capacity to spring freshet and summer rainfall flooding events.

\section{Abbreviations}

AD: Advection Dispersion

BOD: biochemical oxygen demand

COD: chemical oxygen demand

$\operatorname{COD}_{\mathrm{Mn}}:$ chemical oxygen demand by permanganate index method

DO: dissolved oxygen

DP: dissolved phosphorus

HD: Hydrodynamics

$\mathrm{NH}_{4}-\mathrm{N}$ : ammonia nitrogen

PP: particulate phosphorus

RMSE: Root Mean Square Error

TN: total nitrogen

TP: total phosphorous

\section{Declarations}

Ethics approval and consent to participate

Not applicable.

Consent for publication

Not applicable.

\section{Availability of data and materials}

The datasets used and/or analyzed during the current study are available from the corresponding author on reasonable request.

Competing interests 
The authors declare that they have no competing interests.

\section{Funding}

Not applicable.

\section{Authors' contributions}

$\mathrm{CHL}$ and $\mathrm{CY}$ designed the whole research and edit the manuscript. JXL and WWW designed the modelling approach. YZ and HW assisted with collection of field data helped develop and test early drafts of the model, performed the literature review, prepared and edited the manuscript. MK and $\mathrm{CY}$ secured funding for the project, assisted with the interpretation of subsequent data. All authors read and approved the final manuscript.

\section{Acknowledgments}

We would like to thank Mudanjiang Ecology and Environment Bureau for providing information on Lake Jingpo. We would also like to thank HU Wen, CHEN Hong-sen, HUANG Xiao-yi, WANG Jing-jing and GAO Xin-dong for collecting samples and conducting chemical analysis.

\section{Author details}

1: Chinese Research Academy of Environmental Sciences, National Engineering Laboratory for Lake Pollution Control and Ecological Restoration, Beijing 100012, China

b: Shanghai Wuchuan Environment Company, Shanghai 200235, China

c: Nanjing Institute of Environmental Sciences, Ministry of Ecology and Environment, Nanjing 210042, China

\section{References}

Bunt, C.M., Cooke, S.J., Katopodies, C., et al., 1999. Movement and summer habitat of brown trout (Salmo trutta) below a pulsed discharge hydroelectric generating station. Regulated Rivers: Research \& Management, 15(5). 395-403.

Chen, Z.Y., Ma, L.Q., Shu, Y., et al., 2015. Back Analysis of the Draining Process of the Tangjiashan Barrier Lake. Journal of Hydraulic Engineering, 141(4), 05014011.

Chinese Research Academy of Environmental Sciences, 2019. Comprehensive protection scheme on Lake Jingpo. Mudanjiang Bureau of Ecology and Environment.

Cho, J.H., Seo, H.J., 2007. Lake water quality modelling considering rainfall-runoff pollution loads. Journal of Environmental Impact Assessment, 16(5), 341-350. 
Chubarenko I., Tchepikova I. 2001. Modelling of man-made contribution to salinity increase into the Vistula Lagoon (Baltic Sea). Ecological Modelling, 138, 87-100.

Cooney, E.M., McKinney, P., Sterner, R., et al., 2019. Tale of Two Storms: Impact of Extreme Rain Events on the Biogeochemistry of Lake Superior. Journal of Geophysical Research: Biogeosciences, 123(5), 17191731.

Correll, D.L., Jordan, T.E., Weller, D.E., 1999. Transport of nitrogen and phosphorus from Rhode River watersheds during storm events, Water Resources Research, 35, 2513-2521.

DHI (Danish Hydraulic Institute), 2019. MIKE 21 user manual.

Donat, M.G., Lowry, A.L., Alexander, L.V., O'Gorman, P.A., Maher, M., 2016. More extreme precipitation in the world's dry and wet regions. Nature Climate Change, 6, 508-513.

Dorum, A., Yarar, A., Sevimli, M.F., et al., 2010. Modelling the rainfall-runoff data of susurluk basin. Expert Systems with Applications, 37 (2010), 6587-6593.

Environmental Monitoring of China, 2013. Practical manual of environmental monitoring method standards of China, China Environmental Science Press, Beijing.

Gallina, N., Beniston, M., Jacquet, S., 2017. Estimating future cyanobacterial occurrence and importance in lakes: a case study with Planktothrix rubescens in Lake Geneva. Aquatic Sciences, 79, 249-263.

Garg, R.K., Saksena, D.N., Rao, R.J., 2006. Assessment of physico-chemical water quality of Harsi Reservoir, District Gwalior, Madhya Pradesh. Journal of Ecophysiology and Occupational Health, 6(1), 3340.

Groisman, P.Y., Knight, R.W., Easterling, D.R., Karl, T.R., Hegerl, G.C., Razuvaev, V. N., 2005. Trends in intense precipitation in the climate record. Journal of Climate, 18(9), 1326-1350.

Hill, A.R., 1978. Factors affecting the export of nitrate nitrogen from drainage basins in southern Ontario. Water Research, 12:1045-1057.

Jacquet, S., Domaizon, I., Anneville, O., 2014. The need for ecological monitoring of freshwaters in a changing world: A case study of Lakes Annecy, Bourget and Geneva. Environmental Monitoring and Assessment, 186, 3455-3476.

Jin, X.C., 1995. Chinese Lake Environment (III), China Ocean Press, Beijing, China, pp. 80-92. (in Chinese)

Kuang C., Liang H., Mao X., et al., 2017. Influence of Potential Future Sea-Level Rise on Tides in the China Sea. Journal of Coastal Research, 33, (1), 105-117.

Kundzewicz Z.W. 2005. Is the frequency and intensity of flooding changing in Europe? In: Kirch W., Menne B., Bertollini R. (eds) Extreme Weather Events and Public Health Responses. Springer, Berlin, pp 25-32. 
Lesack, L.F.W., 1993. Export of nutrients and major ionic solutes from a rainforest watershed in the central Amazon basin. Water Resources Research, 29, 743-758.

Li, Y., Wang, Y.H., Lv, X.M., et al., 2015. Spatial distribution and temporal change in extreme weather events in three provinces in Northeast China, Resources Science, 37(120), 2501-2513. (in Chinese)

Liu, W., 2013. Analysis of hydrological characteristics of Mudanjiang urban section in the middle reaches of Mudanjiang River basin. Heilongjiang Science and Technology of Water Conservancy, 41(8), 5-9. (in Chinese)

Liu, N., Chen Z., Zhang, J., 2010. Draining the Tangjiashan Barrier Lake, Journal of Hydraulic Engineering, $136,914-923$.

Moore, R.J. 2007. The PDM rainfall-runoff model. Hydrology and Earth System Sciences, 11(1), 483-499.

Roelvink, J.A. Reniers A., van Dongeren, A., de Vries, J., McCall, R., Lescinski, J., 2009a. Modelling storm impacts on beaches, dunes and barrier islands. Coastal Engineering, 56(11-12), 1133-1152.

Salim, A.B., Gowhar, M., Ashok, K., 2015. Pandit Assessing the influence of stream flow and precipitation regimes on water quality of the major inflow stream of Wular Lake in Kashmir Himalaya. Arabian Journal of Geosciences. DOI 10.1007/s12517-015-2083-1.

Smith, J.A., Villarini, G., Baeck, M.L., 2011. Mixture Distributions and the Hydroclimatology of Extreme Rainfall and Flooding in the Eastern United States. Journal of Hydrometeorology, 294-309.

Soltani, P., Askar, M.B., Bahrami, H., et al., 2017. Evaluation of sediment transport in the Naiband gulf area using Mike 21. Open Journal of Geology, 77, 182-192.

Sun, T., Liang, J., Chai, F.X., et al., 2014. Studies on Risk Level Assessment of Barrier Lake Based on BPANN. Applied Mechanics and Materials, 644, 5676-5680.

Wang, X., Liu, L.S., Li, L., et al., 2015. Correlation analysis of algae composition and environmental factors in Lake Jingpo. China Environmental Science, 35(11), 3403-3413. (in Chinese)

Warren, I.R., Bach, H.K., 1992. MIKE 21: a modelling system for estuaries, coastal waters and seas. Environmental Software, 7, 229-240.

Williams, J.J., Esteves, L.S., Conduche, T., et al., 2014. Using combined modelling approaches to improve coastal defence design: a case study at Hopton, UK. In: Green, A.N. and Cooper, J.A.G. (eds.), Proceedings 13th International Coastal Symposium (Durban, South Africa), Journal of Coastal Research, Special Issue 70, 18-22.

Winterbourn, J., Clements, K., Lowther, J. A., et al., 2016. Use of Mytilus edulis biosentinels to investigate spatial patterns of norovirus and faecal indicator organism contamination around coastal sewage 
discharges. Water Research, 105, 241-250.

Wu, C., 2016. Hydraulics. Higher Education Press. Beijing. (in Chinese)

Xu M., 2009. Change detection of the tangjiashan barrier lake based on multi-source remote sensing data. In Proc. Int. Geosci. Remote Sens. Symp. (IGARSS), Cape Town, South Africa, vol. 1,pp. 2683-2686.

Yang, X., Chen, J., Yan, L., 2010. Resource characteristics and protection of Lake Jingpo National Geopark in Heilongjiang Province. Heilongjiang Science and technology information, 32:69-70, 251. (in Chinese)

Yu, J.H., Gong, Y.F., Mao, W.H., 2019. Comparative Analysis on Two Extreme Severe Precipitation Events in Yongji County, Jilin Province in July 2017. Journal of Chengdu University of Information Technology, 34(3), 287-296. (in Chinese)

Zhang, W., Villarini, G., Vecchi, G.A. 2017. Impacts of the Pacific Meridional Mode on June-August precipitation in the Amazon River Basin. Quarterly Journal of the Royal Meteorological Society, 143(705), 1936-1945

Zheng, D.C., Cui, G., Jin, Z., et al., 2006. Hydrological characteristics of the upstream of Mudanjiang River. Water Resources \& Hydropower of Northeast China, 12, 37-37. (in Chinese)

\section{Figures}

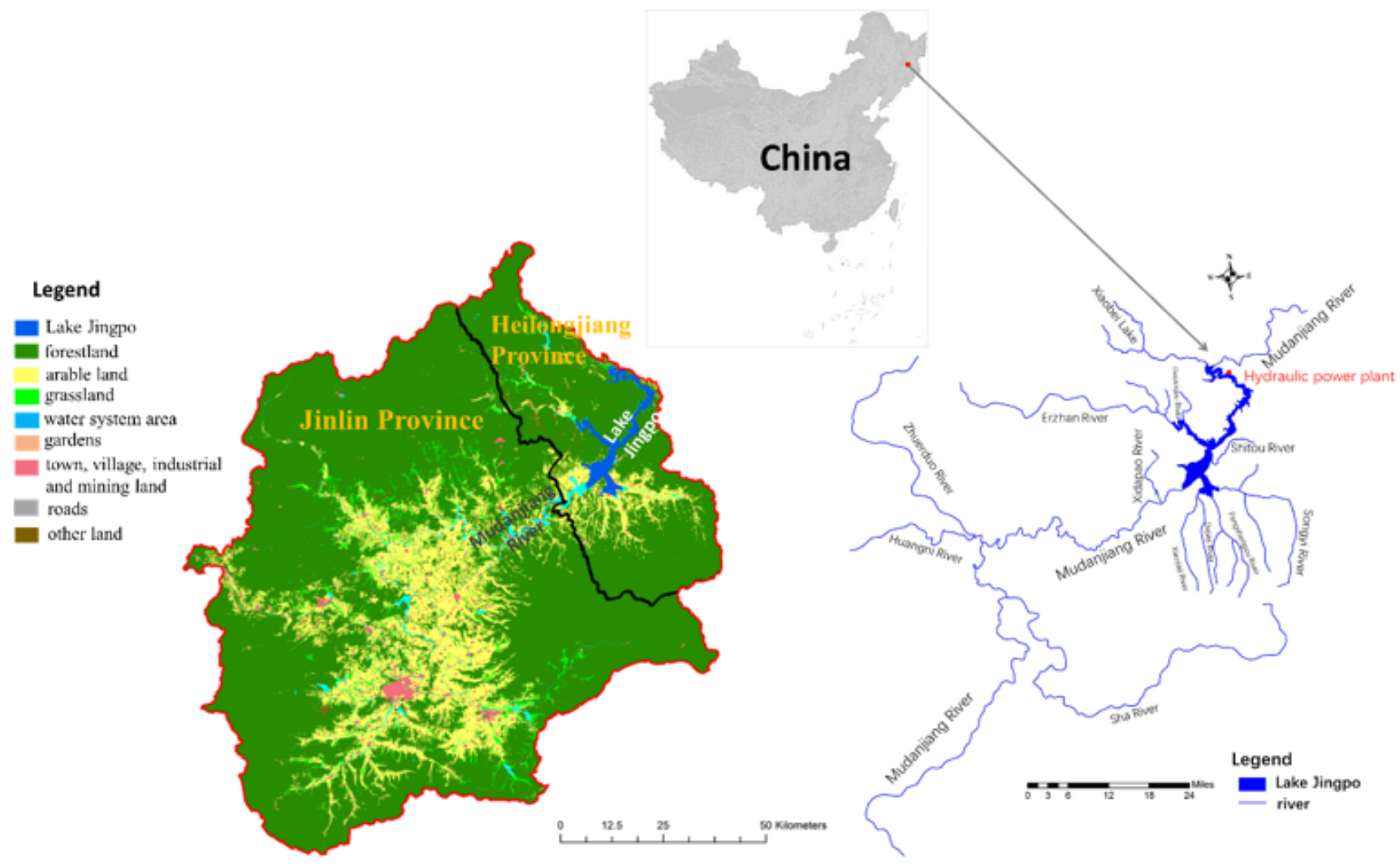


Figure 1

Lake Jingpo location, catchment, land use, and water system. Note: The designations employed and the presentation of the material on this map do not imply the expression of any opinion whatsoever on the part of Research Square concerning the legal status of any country, territory, city or area or of its authorities, or concerning the delimitation of its frontiers or boundaries. This map has been provided by the authors.

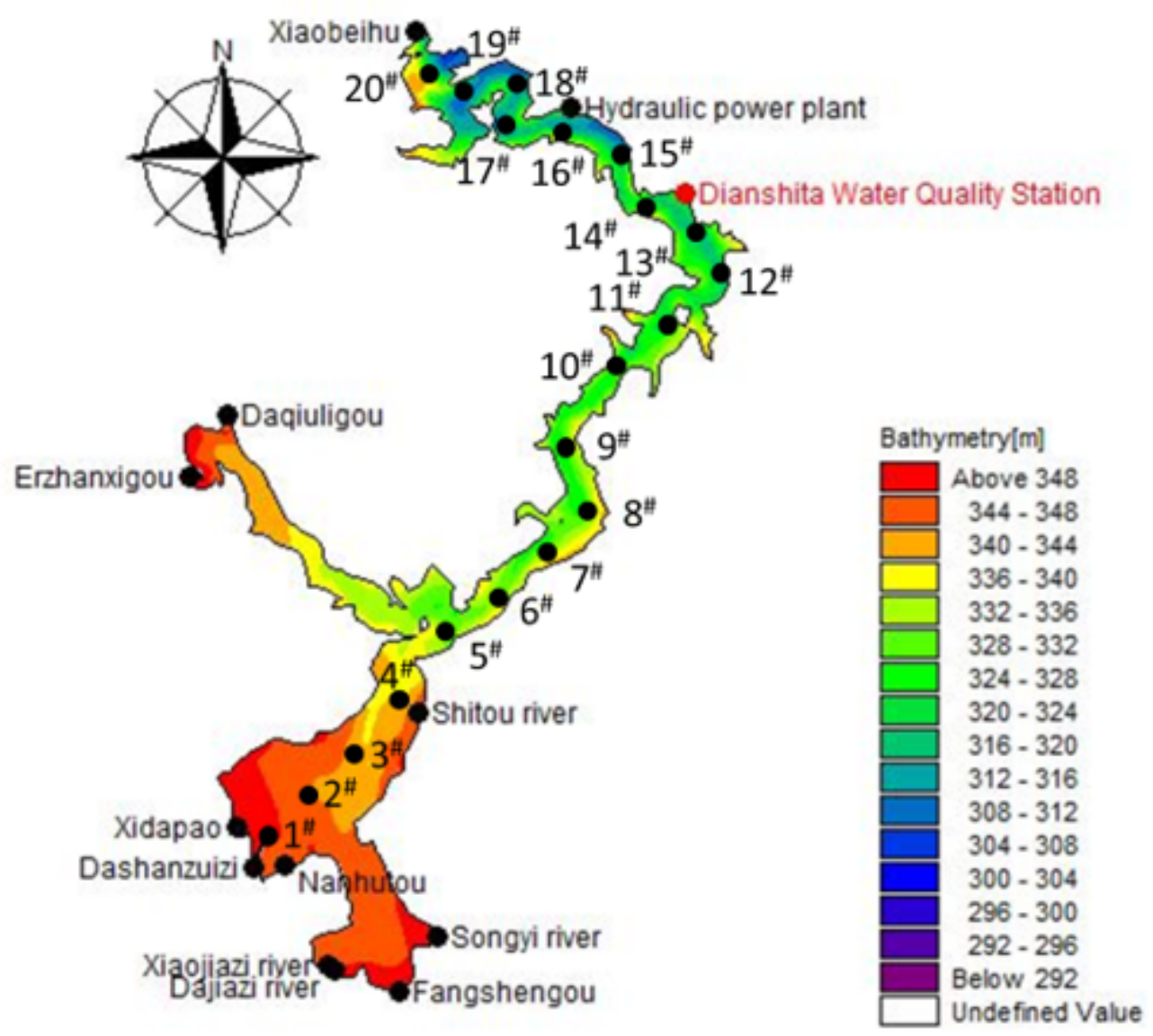

Figure 2

Underwater elevation profile of Lake Jingpo using Yellow Sea Height data and water quality sampling sites 


\section{Processes affecting}

nitrogen transport.

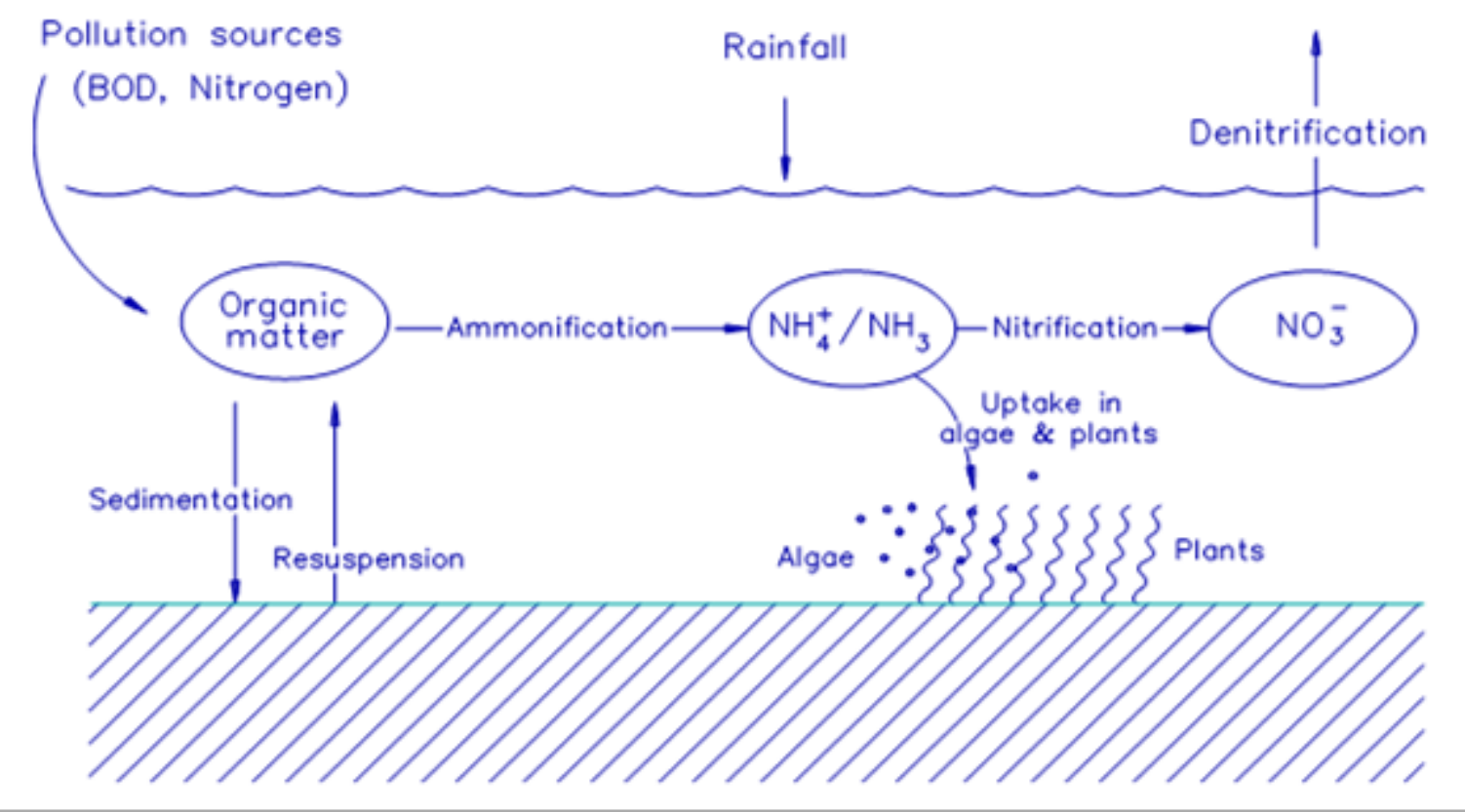

\section{Figure 3}

Nitrogen compounds and processes included in MIKE 21 AD convection and diffusion module. Source: DHI, 2019.

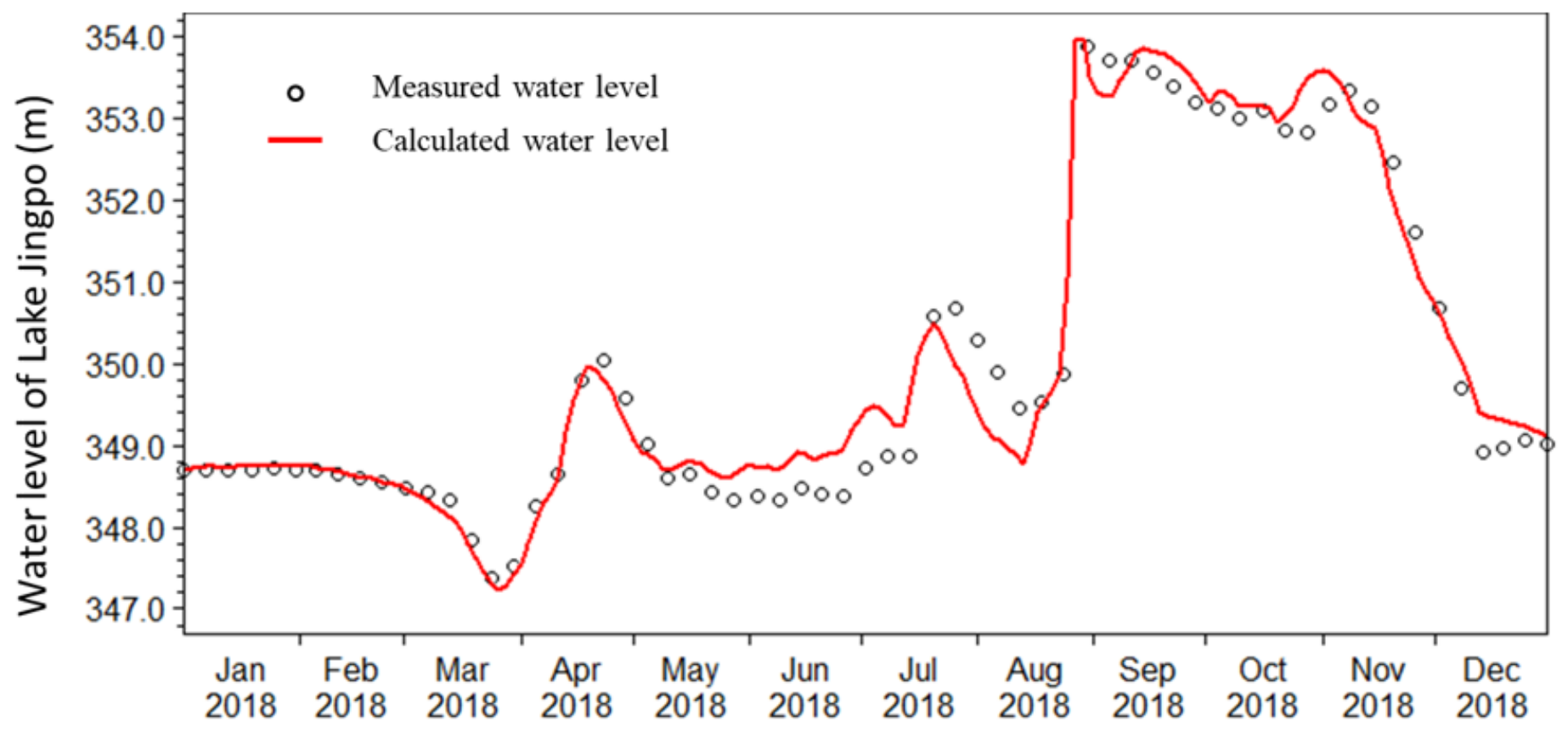

Figure 4 
Flow model calibration results for Lake Jingpo
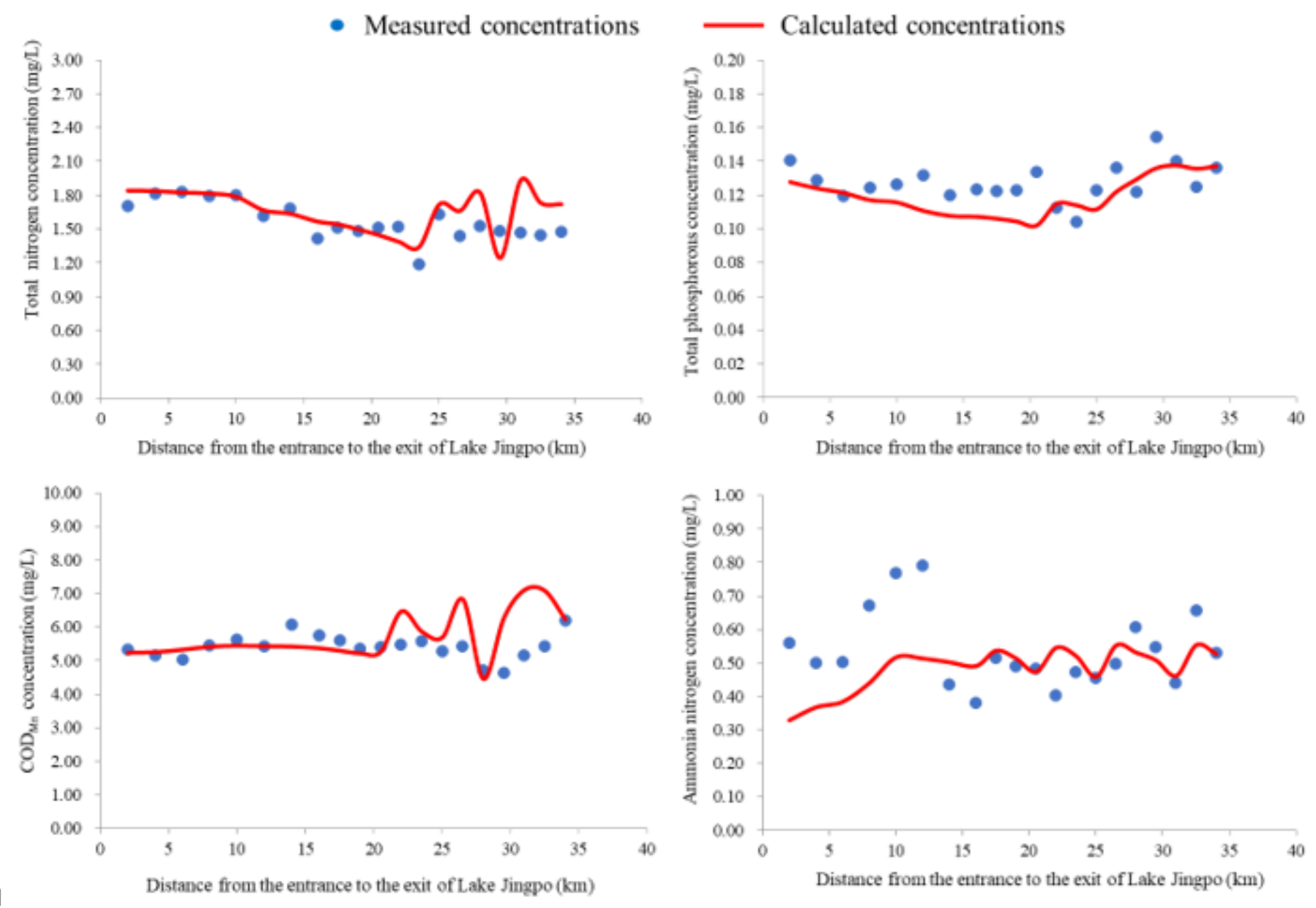

Figure 5

Water quality model calibration results for Lake Jingpo 
Fig. 6

Simulated TN [mol]
Measured TN [mol]

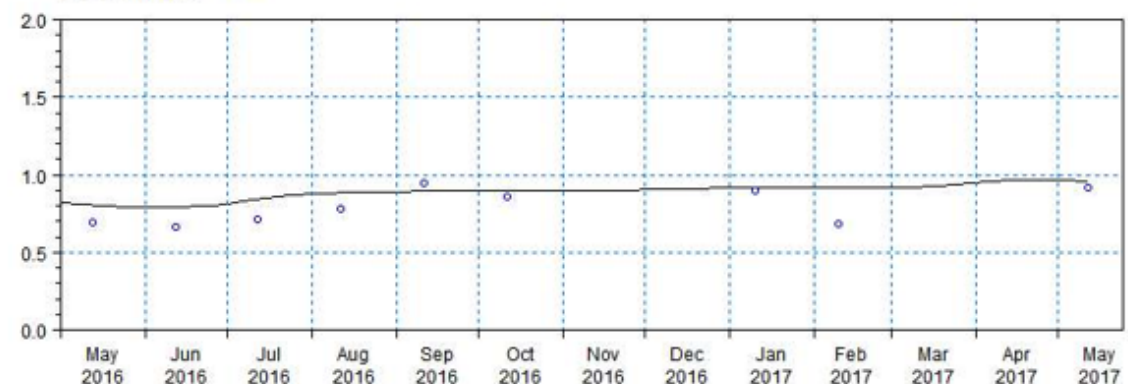

Simulated TP [mgl] -

Measured TP [mol] 00

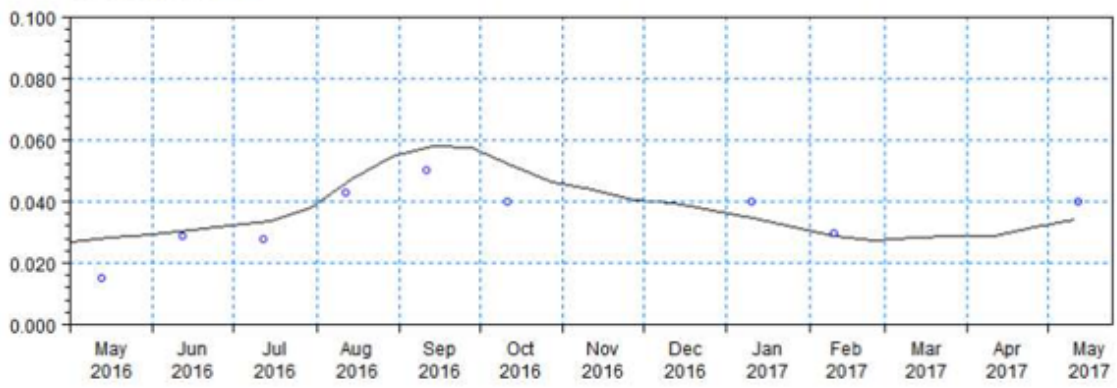

Simulated COOmn $[\mathrm{mg} /]$
Measured CODmn [mg/]

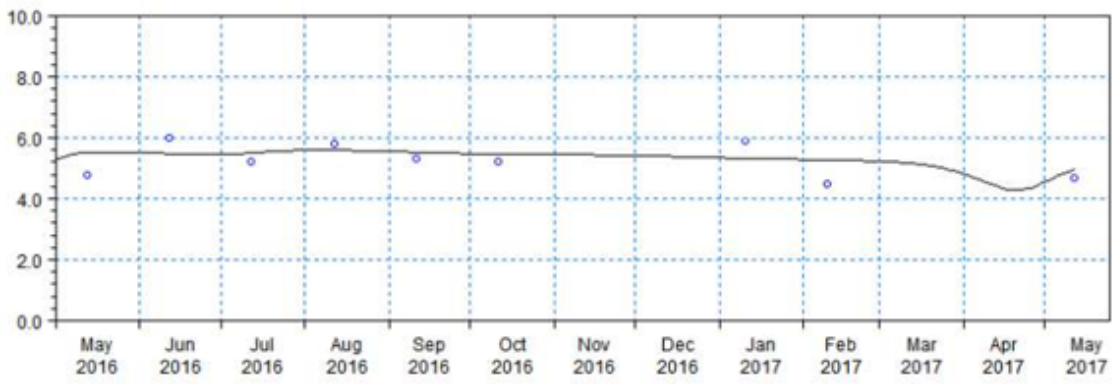

Simulated NH4-N [mgl]

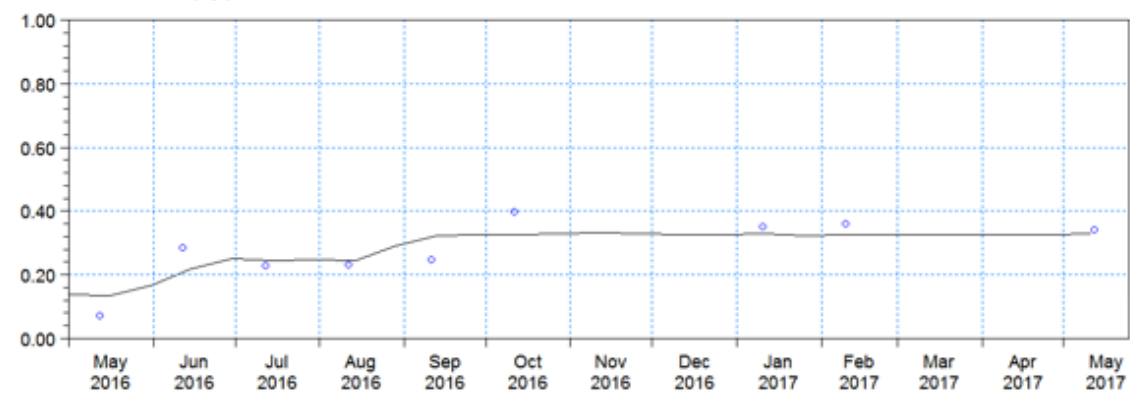

\section{Figure 6}

Simulated and measured water quality comparisonof Lake Jingpo 


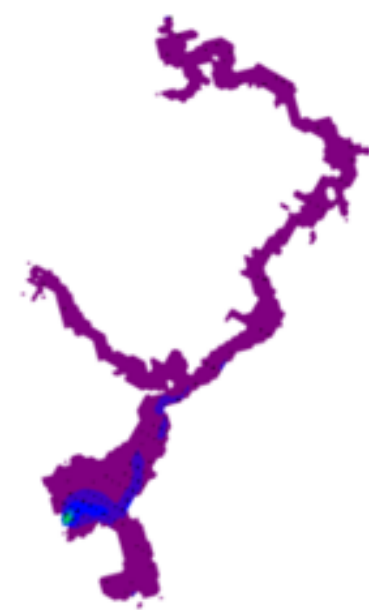

March

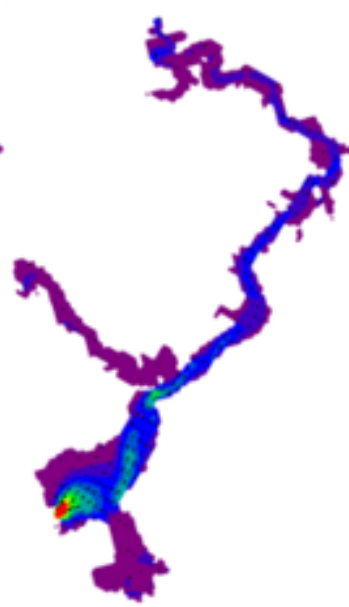

April
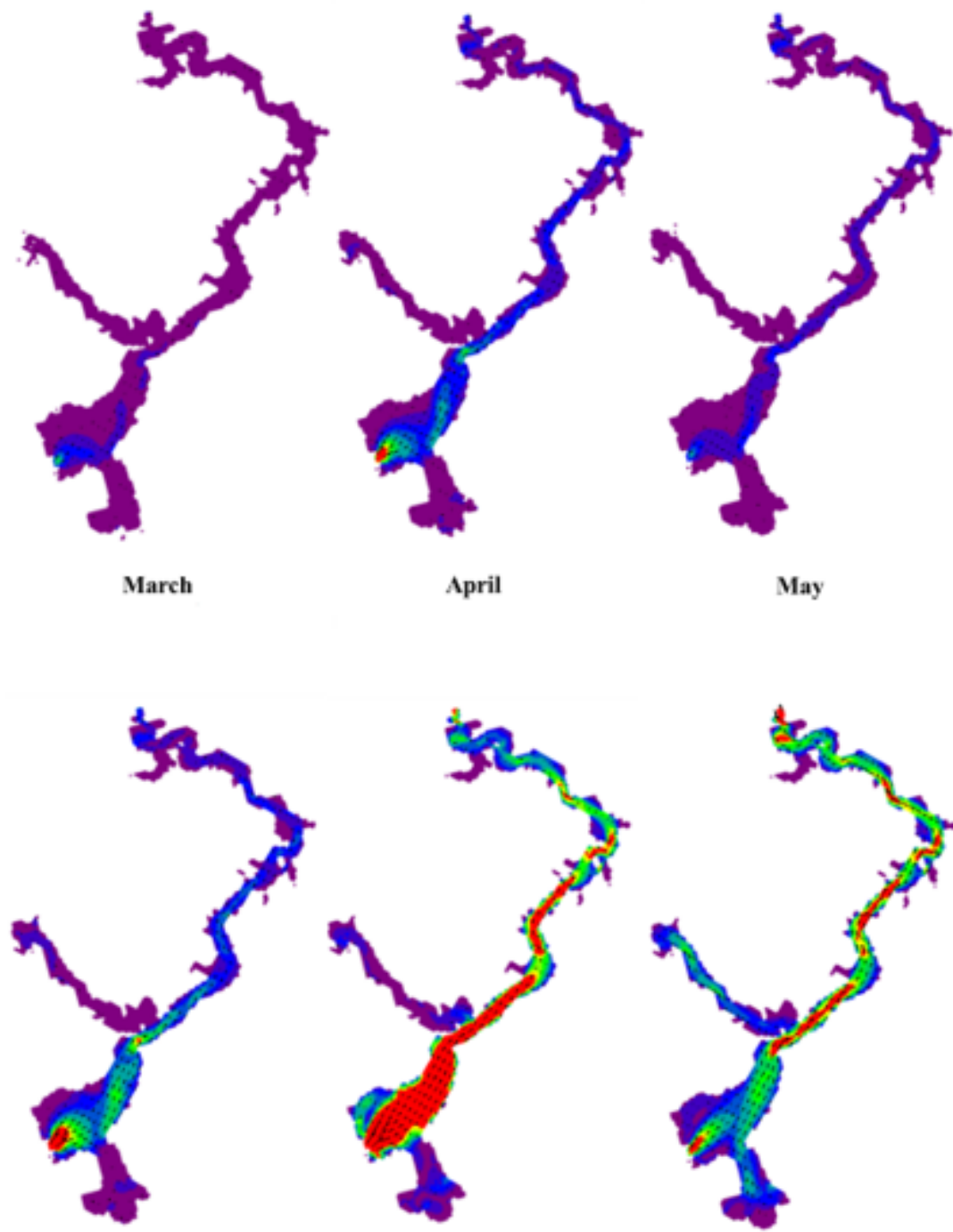

July

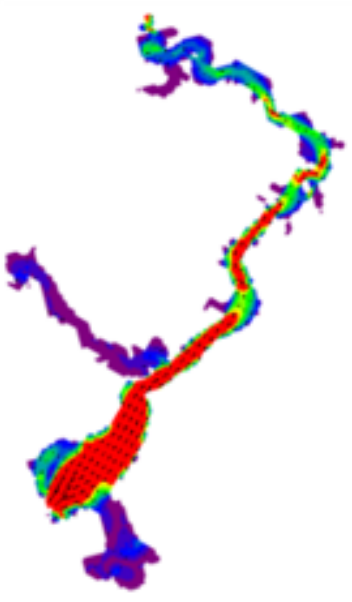

August
May
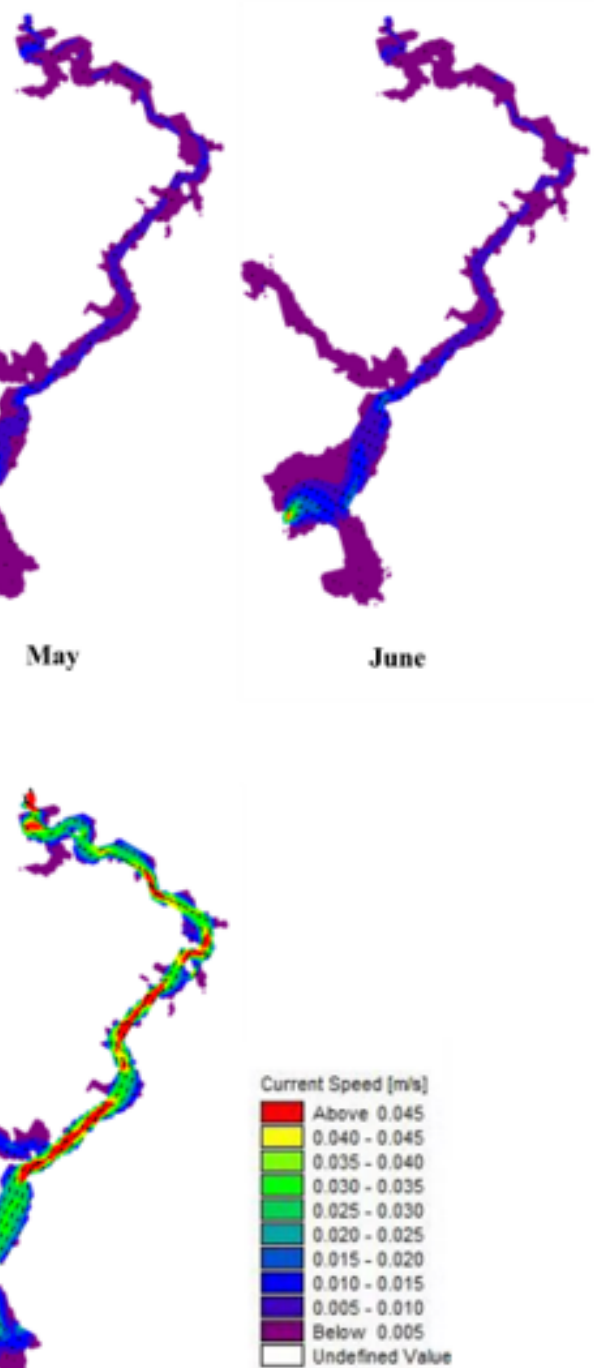

September

Figure 7

Flow field distribution of Lake Jingbo from March to September, 2018 

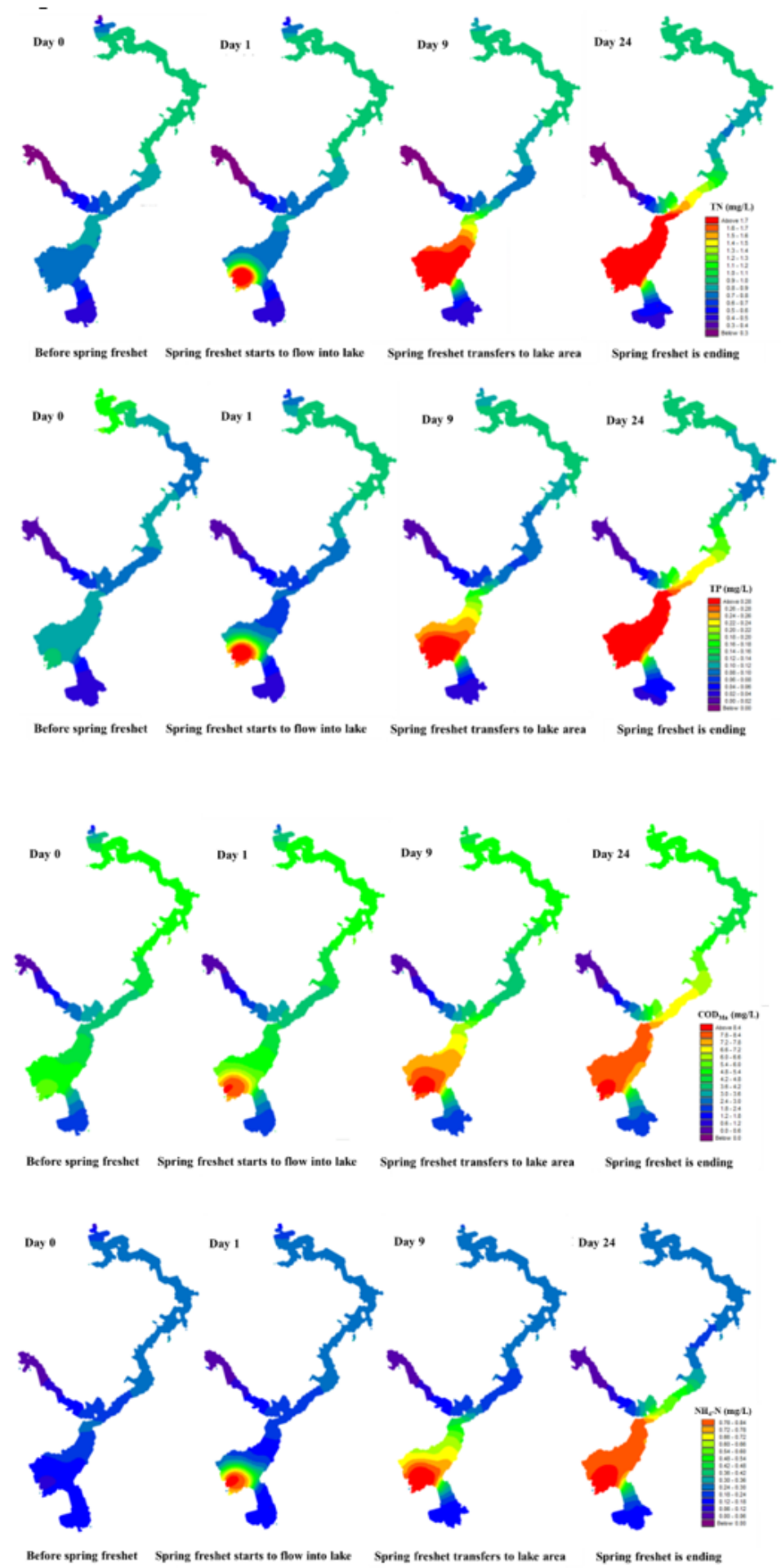

Figure 8

Impact of spring freshet flooding on the water quality of Lake Jingpo 


$$
\begin{aligned}
& 383 \\
& 3303 \\
& 383 \\
& 3337
\end{aligned}
$$



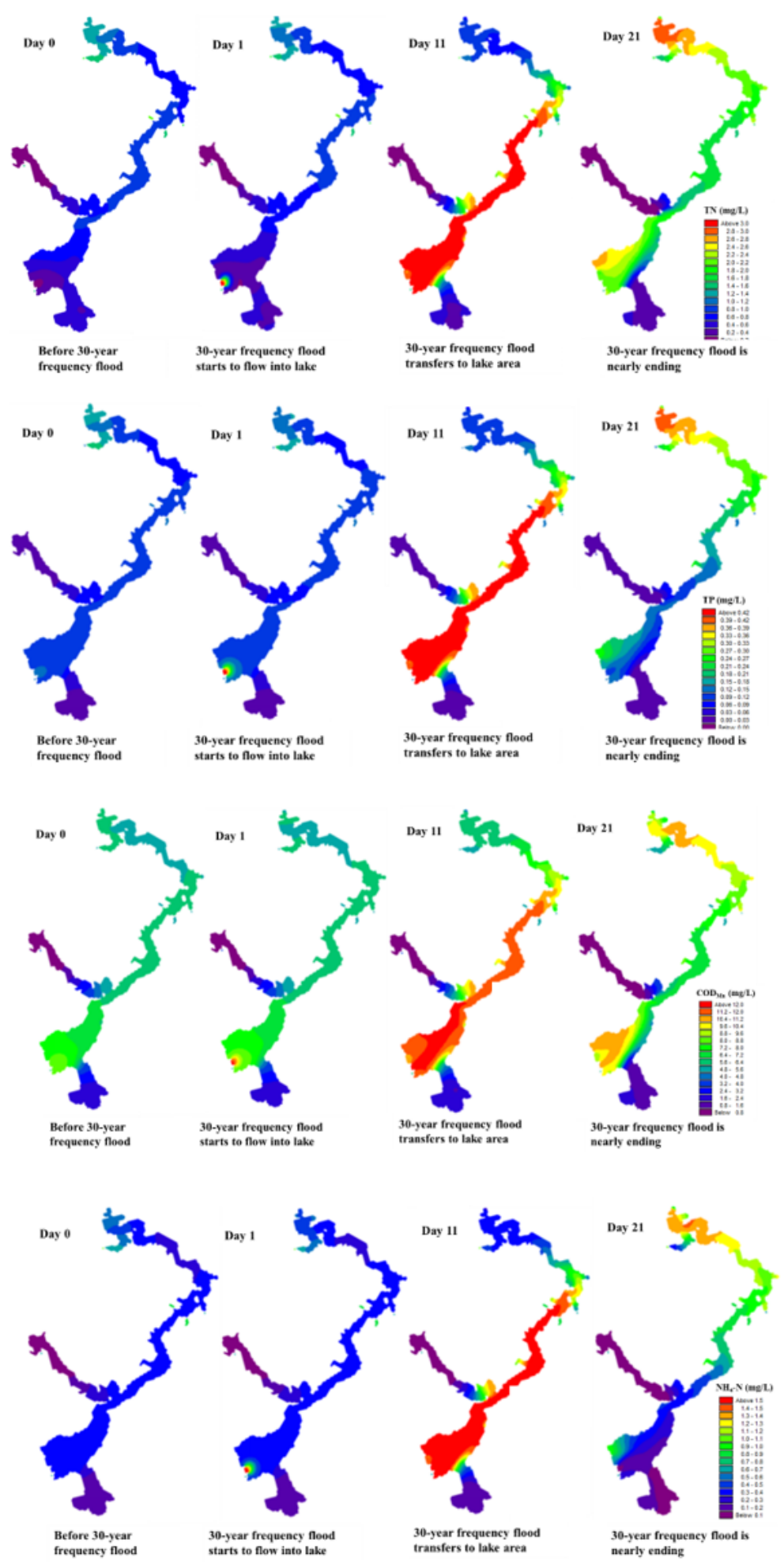

Figure 10

Impact of 30-year frequency flooding on the water quality of Lake Jingpo

\section{Supplementary Files}

This is a list of supplementary files associated with this preprint. Click to download. 
- Equations.docx

- Hydraulicpowerplant.xls

- Fig.S1DailyaverageflowatDashanzuiziStationin2018.docx

- RiverwaterqaulitySupportdata.xlsx

- RIVERFLOWSupportdata.xIsx 